\title{
PENGARUH KEPEMIMPINAN KETUA KELOMPOK TERHADAP TINGKAT KEMANDIRIAN ANGGOTA KELOMPOK DI GABUNGAN PETANI ORGANIK (GPO) NYI-SRI KECAMATAN CIANJUR KABUPATEN CIANJUR
}

\author{
Oleh : \\ Tri Rahayu S.P * \\ Rosda Malia, S.P., M.Si **
}

\begin{abstract}
ABSTRAK
Salah satu aspek pendorong dalam mewujudkan tingat kemandirian adalah berjalannya kepemimpinan ketua kelompok dalam kelompok tani itu sendiri. Tujuan penelitian ini : (1) Mengetahui kepemimpinan ketua kelompok di GPO Nyi-Sri Kecamatan Cianjur, (2) Mengetahui tingkat kemandirian anggota kelompok di GPO Nyi-Sri Kecamatan Cianjur, (3) Mengetahui pengaruh kepemimpinan ketua kelompok terhadap tingkat kemandirian anggota kelompok tani di GPO Nyi-Sri Kecamatan Cianjur. Penelitian dilaksanakan dari Bulan Januari sampai dengan Bulan Juli 2017 di GPO Nyi-Sri Kecamatan Cianjur. Penelitian ini merupakan penelitian kualitatif. Analisis yang digunakan yaitu deskriptif, metode pengolahan data sebagai berikut : (1) Skala likert, (2) Korelasi pearson product moment, (3) Regresi linier sederhana. Berdasarkan hasil analisis likert, kepemimpinan ketua kelompok memperoleh skor rata - rata 4,03 (baik) dan tingkat kemandirian anggota kelompok dengan skor rata - rata 4,05 (baik). Analisis korelasi pearson product moment menunjukkan nilai 0,787 (hubungan keduanya sangat kuat). Analisis regresi linier sederhana menunjukan nilai sig $0,000<0,05(\alpha)$ dan nilai t hitung sebesar 6,745 > 1,697 ( $\mathrm{t}$ tabel). Hasil tersebut menunjukkan, terdapat pengaruh yang signifikan antara kepemimpinan ketua kelompok terhadap tingkat kemandirian anggota kelompok GPO NyiSri Kecamatan Cianjur.
\end{abstract}

Kata Kunci : kepemimpinan ketua kelompok, kemandirian angoota kelompok, korelasi, regresi.

\begin{abstract}
One of motivational aspect in realizing the level of independency is the leadership character of farmer's group leader. Moreover, the purposes of this study are as follows: (1) To Explore the leadership characteristics of the group leader in GPO Nyi-Sri District Cianjur, (2) To assess the independency level of the members of GPO Nyi-Sri District Cianjur, (3) To assess the influence of leader on the independency level of farmer group members in GPO Nyi-Sri District Cianjur. In the fact, the study conducted from January to July 2017 at GPONyi-Sri District Cianjur. The method used in determining the respondents was using a sampling census method. This research is a qualitative research and the data analysis used the descriptive analysis by using some data processing method as follows: (1) Likert-scale analysis, (2) Pearson product moment correlation analysis, (3) Simple linear regression analysis. Based on the results of the Likert analysis, the leadership of the group leader obtained an average score of 4.03 (good) and an average score of 4.05 (good) for the level of independence of members of the Nyi-Sri Group of Cianjur GPO.Moreover, the result of Pearson product moment correlation analysis shows the value of 0.787 (the relationship is very strong).In the last analysis by using simple linear regression analysis shows that sig 0,000 <0,05 (a) and $t$ value is 6,745> 1,697 (t table).It conclude the results of the analysis indicate that there is a significant influence between the leadership of the group leader on the level of independence of members of the group GPO Nyi-Sri District Cianjur.
\end{abstract}

Key words : leadership of the group leader, independence of group members, correlation, regresion.

* Alumni Faster UNSUR

** Dosen Faster UNSUR

Pengaruh Kepemimpinan Ketua Kelompok Terhadap

Tingkat Kemandirian Anggota Kelompok Di Gabungan

Petani Organik (Gpo) Nyi-Sri Kecamatan Cianjur

Kabupaten Cianjur

TRI RAHAYU dan ROSDA AMALIA 


\section{PENDAHULUAN}

\section{Latar belakang}

Untuk meningkatkan kontribusi sektor pertanian terhadap penurunan angka kemiskinan, perlu adanya partisipasi aktif dari masyarakat dalam proses pembangunan pertanian berkelanjutan sehingga dapat meningkatkan penurunan angka kemiskinan. Sektor pertanian memerlukan dukungan sumber daya manusia yang berkualitas. Salah satu upaya mewujudkan sumber daya manusia yang berkualitas adalah dengan cara pembentukan kelompok tani, sekaligus pembinaan melalui penyuluhan pertanian. Pendekatan kelompok tani dipandang lebih efisien dan dapat menjadi media untuk terjadinya proses belajar dan berinteraksi dari para petani, sehinggadiharapkan terjadi petani ke arah yang lebih baik atau berkualitas. Pembentukan dan pengembangan kelompok tani diarahkan pada peningkatan peranan, peran serta petani dan anggota masyarakat lainnya denganmenumbuhkembangkan kerjasama antar petani dengan pihak lain, dalam mengembangkan usahataninya. Selain itu dengan bergabungnya petani dalam wadah kelompok tani dapat membantu menggali potensi, memecahkan masalahusahatani anggotanya agar lebih efektif, memudahkan mengakses informasi, pasar, teknologi, permodalan dan sumber daya lainnya.

Pembentukan kelompok tani telah berjalan di berbagai wilayah Kabupaten Cianjur, salah satunya Gabungan Petani Organik(GPO) Nyi-Sri, yang menaungi seluruh kelompok tani yang menerapkan sistem pertanian organik. GPO Nyi-Sri suatu wadah perkumpulan petani organik yang saling berinteraksi dan bertukar informasi terkait pertanian organik. Kemudian dikembangkan dalam usaha taninya guna meningkatkan kesejahteraan para petani itu sendiri disamping berperan untuk perekonomian nasional, penanggulangan kemiskinan serta meningkatkan dan melestarikan swasembada pangan.
Kegiatan tersebut juga merupakan upaya membentuk kemandirian kelompok tani sebagai wadah petani dalam melakukan aktivitasnya. Upaya ini merupakan tindak lanjut dari Peraturan Menteri Pertanian Nomor : 273/Kpts/OT.160/4/2007. Sehingga kelompok tani memiliki kedudukan yang strategis di dalam mewujudkan petani yang berkualitas. Petani yang berkualitas antara lain dicirikan oleh adanya kemandirian dan ketangguhan dalam berusahatani.

Untuk mencapai petani yang berkualitas, maka menjadi suatu keharusan bahwa kelompok tani yang ada harus memiliki gerak atau kekuatan yang dapat menentukan dan mempengaruhi perilaku kelompok dan anggota-anggotanya dalam mencapai tujuan-tujuan secara efektif. Dengan kata lain kelompok tersebut harus berfungsi efektif untuk kepentingan para anggotanya. Salah satu faktor penting untuk terwujudnya kelompok tani yang efektif adalah berjalannya kepemimpinan dari ketua kelompok tani tersebut. Dengan berjalannya kepemimpinan di kelompok tani, maka akan dimungkinkan kelompok tani tersebut mencapai kemandirian, kemandirian anggota kelompok adalah tingkat keberhasilan kelompok untuk mencapai tujuannya.

Sejak Tahun 2009 Gabungan Petani Organik (GPO) Nyi. Sri telah terbentuk di Kabupaten Cianjur dan memiliki koordinator yang menangani pengembangan pertanian organik ditiap kecamatan, GPO Kecamatan Cianjur yang diketuai oleh Bpk. Hj. Usman dan terbentuk dibawah koordinator Bpk. Ajan Suparjan, keduanya merupakan pimpinan yang berperan sebagai kekuatan bagi GPO Nyi. Sri Kecamatan Cianjur.Akan tetapi, jika dilihat dari lama berdirinya GPO Nyi. Sri Kecamatan Cianjur, perkembangannya relatif rendah. Terlihat dari jumlah anggota yang masih sedikit dan struktur organisasi yang masih sederhana. Disamping itu, tingkat inisiatif untuk berpartisipasi aktif terhadap pelatihanpelatihan yang ada masih kurang atau belum terlihat, orang yang dilibatkan dalam pelatihan cenderung itu-itu saja 
(ketua kelompok/sekertaris), serta program yang dihasilkan masih belum lengkap, baru sebatas pembelajaran budidaya tanaman padi organik, sehingga belum dapat meningkatkan pendapatan anggota kelompok.

Persoalan-persoalan tersebut salah satunya terjadi karena tingkat kemandirian anggota yang masih rendah dan jika dikaitkan dengan peran ketua kelompok hubungannya sangatlah erat, karena suatu kelompok tani dimungkinkan mencapai kemandirian apabila kepemimpinannya berjalan atau peran ketua kelompoknya berfungsi secara baik. Berdasarkan hal tersebut, perlu adanya pengkajian terkait peran ketua kelompok terhadap kemandirian anggota kelompok tani di GPO Nyi-Sri Kecamatan Cianjur. Hasil dari pengkajian diharapkan menjadi masukan untuk meningkatkan kinerja kepengurusan dan kemandirian anggota kelompok tani di GPO Nyi-Sri Kecamatan Cianjur.

\section{Tujuan Penelitian}

Adapun tujuan dari penelitian ini adalah sebagai berikut :

1) Mengetahui kepemimpinan ketua kelompok di GPO NyiSri Kecamatan Cianjur.

2) Mengetahui tingkat kemandirian anggota kelompok di GPO Nyi-Sri Kecamatan Cianjur.

3) Mengetahui pengaruh kepemimpinan ketua kelompok terhadap tingkat kemandirian anggota kelompok tani di GPO Nyi-Sri Kecamatan Cianjur.

\section{TINJAUAN PUSTAKA}

\section{Pengertian Kepemimpinan}

Kepemimpinan secara umum menurut Onong (1981) menunujukkan proses kegiatan seseorang dalam memimpin, membimbing, mempengaruhi atau mengontrol pikiran, perasaan atau tingkah laku orang lain. Kegiatan tersebut dapat dilakukan melalui suatu karya, seperti buku, lukisan dan sebagainya atau melalui kontak pribadi anatar seseorang dengan orang lain secara tatap muka (face to face).

\section{Kemandirian Anggota Kelompok Tani}

Soetomo (2012) menyatakan bahwa kemandirian merupakan salah satu komponen sikap individu dalam merespon proses pemberdayaan, sehingga mampu menggunakan sumber daya sendiri berdasarkan pengetahuan yang diperoleh, kerja sendiri dan dalam lingkungan yang diciptakan sendiri berdasarkan keterampilan yang diperoleh. Kemandirian bukan berarti mampu hidup sendiri tetapi mandiri dalam pengambilan keputusan, yakni memiliki kemampuan untuk memilih dan berani untuk menolak segala bentuk dan kerjasama yang tidak menguntungkan.

\section{METODE PENELITIAN}

Penelitian dilaksanakan di Gabungan Petani Organik (GPO) Ny-Sri Kecamatan Cianjur yang beralamat di Kelurahan Bojongherang Kecamatan Cianjur Kabupaten Cianjur. Waktu pelaksaan penelitian skripsi dilakukan sejak Bulan Januari sampai dengan Bulan Juli 2017.

\section{Populasi dan Responden Penelitian}

\section{Populasi menurut Sugiyono} (2007) memberikan definisi sebagai berikut: wilayah generalisasi yang terdiri dari obyek atau subyek yang mempunyai kualitas dan karakteristik tertentu yang ditetapkan oleh peneliti untuk dipelajari kemudian ditarik kesimpulannya. Sedangkan responden merupakan bagian dari jumlah dan karakteristik yang dimiliki oleh populasi. Populasi bukan sekedar jumlah yang ada pada obyek/subyek yang diteliti, melainkan seluruh karateristik atau sifat yang dimiliki oleh obyek/subyek itu sendiri (Sugiyono, 2011). Dari penjelasan ahli tersebut, maka peneliti menetapkan yang dijadikan populasi 
dalam penelitian ini adalah pengurus dan anggota GPO Ny-Sri Kecamatan Cianjur yang aktif. Pengurus dan anggota yang aktif berjumlah sebanyak 30 orang, karena jumlah anggota hanya sebanyak 30 orang, jadi semua populasi dijadikan responden.

\section{Teknik Pengumpulan Data}

Teknik pengumpulan data adalah cara yang digunakan peneliti untuk mendapatkan data dalam suatu penelitian. Berikut adalah langkah yang digunakan peneliti dalam pengumpulan data :

\section{1) Observasi}

Sugiyono (2012) menyatakan bahwa, observasi adalah dasar semua ilmu pengetahuan. Observasi tidak selalu dengan subyek / manusia tetapi juga obyek-obyek alam yang lain. Observasi yang dilakukan dalam penelitian ini, dilakukan pada anggota GPO Ny-Sri Kecamatan Cianjur selaku subyek, observasi tersebut berupa pengamatan secara langsung kegiatan dalam kelompok seperti : diskusi kelompok, pelatihan/penyuluhan bersama PPL, kegiatan bercocok tanam, sampai perlakuan setelah panen seperti pengemasan dan lain-lain.

\section{2) Wawancara/interview}

Sugiyono (2012), mendefinisikan bahwa wawancara merupakan pertemuan dua orang untuk bertukar informasi dan ide melalui tanya jawab, sehingga dapat dikonstruksikan makna dalam suatu topik tertentu. Dalam penelitian ini, peneliti melakukan wawancara pada pengurus dan anggota yang aktif di GPO Nyi-Sri Kecamatan Cianjur.

\section{3) Angket/kuesioner}

$$
\text { Menurut Sugiyono (2011), }
$$

kuesioner merupakan teknik pengumpulan data yang dilakukan dengan cara memberi seperangkat pertanyaan atau pernyataan secara tertulis kepada responden untuk dijawabnya. Dari penjelasan tersebut, untuk memudahkan perolehan informasi yang diharapkan, peneliti menyusun bentuk pertanyaan atau pernyataan yang diambil dari indikatorindikator variabel penelitian. Angket/kuesioner tersebut disebarkan agar dapat memudahkan pengukuran sikap, kondisi ataupun gejala-gejala yang terkait dalam penelitian.

\section{Jenis Data}

Menurut Lungan (2006), data primer dan data sekunder dibedakan berdasarkan cara memperolehnya. Data merupakan keterangan-keterangan tentang suatu hal, dapat berupa sesuatu yang diketahui atau dianggap (Hasan, 2009). Data yang digunakan dalam penelitian ini berupa data sekunder dan data primer. Data primer yang diperoleh adalah berdasarkan wawancara langsung dan penyebaran angket/kuesioner pada petani yang telah ditentukan, yaitu pengurus dan anggota GPO $\mathrm{Ny}-$ Sri Kecamatan Cianjur. Data sekunder diperoleh dari Dinas Pertanian Tanaman Pangan dan Holtikultura Kabupaten Cianjur. Dilengkapi dengan artikel, jurnal serta penelitian-penelitian terdahulu.

\section{Metode Pengolahan Data}

Pengolahan data adalah suatu proses dalam memperoleh data ringkasan atau angka ringkasan dengan menggunakan cara-cara atau rumus-rumus tertentu. Pengolahan data bertujuan untuk mengubah data mentah dari hasil pengukuran menjadi data yang lebih halus, sehingga memberikan arah untuk pengkajian lebih lanjut (Hasan, 2009). Dalam penelitian ini peneliti memilih jenis penelitian kualitatif dengan menggunakan analisis skala likert. Data diolah dengan analisis korelasi Pearson Product Moment dan analisis regresi linier sederhana.

\section{HASIL DAN PEMBAHASAN}




\section{Profil Kelembagaan GPO Nyi-Sri Kecamatan Cianjur}

Pada Tanggal 27 Juli 2009 telah didirikan GPO Nyi-Sri yang merupakan organisasi gabungan petani organik yang menampung aspirasi maupun aktifitas petani yang telah menerapkan sistem organik. Organisasi ini merupakan wadah atau tempat belajar para petani organik yang bertujuan untuk mengembangkan inovasi pertanian organik di Kabupaten Cianjur, meningkatkan kualitas petani dan meningkatkan taraf hidup petani organik.

GPO Nyi-Sri ini terbentuk atas dasar inisiatif petani setelah beberapa kali mengikuti pelatihan-pelatihan System of rice intensification (SRI). Hingga diambillah tema pelatihan tersebut menjadi nama gabungan petani organik tersebut yaitu "GPO Nyi-Sri” yang berdasarkan musyawarah dan mufakat bersama.

Anggota GPO Nyi-Sri tersebar hampir diseluruh kecamatan yang ada di Kabupaten Cianjur, termasuk Kecamatan Cianjur yang dijadikan sebagai wilayah penelitian. GPO Nyi-Sri Kabupaten Cianjur mempunyai beberapa prinsip dasar, yaitu diantaranya sebagai berikut :
1. Peningkatan pemberdayaan sumber daya manusia.
2. Melakukan pembenahan tanah.
3. Melestarikan ekosistem.
4. Efisiensi penggunaan air.
Berdasarkan prinsip tersebut, aktivitas yang dilakukan oleh pengurus dan anggota GPO Nyi-Sri merupakan suatu langkah dasar bagi pertumbuhan dan perkembangan pertanian organik yang dapat memberikan energi positif untuk meningkatkan keseluruhan aspek pertanian. Prinsip-prinsip ini diterapkan dalam pertanian dengan pengertian luas, termasuk bagaimana para anggota kelompok tani memelihara tanah, air, tanaman dan hewan untuk menghasilkan, mempersiapkan dan menyalurkan pangan dan produk lainnya. Prinsip - prinsip tersebut menyangkut bagaimana kelompok tani berhubungan dengan lingkungan hidup, berhubungan satu sama lain dan menentukan warisan untuk generasi mendatang.

\section{Responden Penelitian}

Penelitian ini hanya melibatkan responden yang memiliki status keanggotaan aktif. Anggota yang aktif dapat berkontribusi dan bersinergis dengan kelompoknya, sehingga mengalami langsung bagaimana kerjasama dan komunikasi yang terjalin dalam kelompok.

Karakteristik responden akan dibahas berdasarkan variabel : umur, jenis kelamin, pendidikan terakhir, luas lahan, status kepemilikan lahan dan lama berusaha tani. Berikut adalah penjelasan ketiga variabel tersebut :

\section{1) Umur}

Menurut UU No. 13 Tahun 2003 angkatan kerja adalah setiap orang yang mampu melakukan pekerjaan guna menghasilkan barang dan atau jasa baik untuk memenuhi kebutuhan sendiri maupun untuk masyarakat. Secara garis besar penduduk suatu negara dibedakan menjadi dua kelompok, yaitu angkatan kerja dan bukan angkatan kerja. Tingkatan umur dapat memudahkan peneliti mengetahui mana saja anggota yang termasuk ke dalam katagori umur yang belum produktif (bukan angkatan kerja), produktif (angkatan kerja) ataupun sudah tidak produktif (lanjut usia). Pada umumnya tingkat umur dapat dilihat berdasarkan batas kerja/angkatan kerja, yaitu sebagai berikut :

Tabel 1. Tingkatan Usia Berdasarkan Batas Kerja/Angkatan Kerja

\begin{tabular}{|l|l|l|}
\hline No. & \multicolumn{1}{|c|}{ Batas Usia } & \multicolumn{1}{c|}{ Katagori } \\
\hline 1 & $<15$ tahun & belum produktif / bukan angkatan kerja \\
\hline 2 & 16 tahun -64 tahun & usia produktif / angkatan kerja \\
\hline 3 & $>64$ tahun & tidak lagi produktif / lanjut Usia \\
\hline
\end{tabular}

Sumber : UU Ketenagakerjaan, 2003. 
Berikut adalah karakteristik responden berdasarkan tingkat usia :

Tabel 2. Karakteristik Responden Berdasarkan Usia

\begin{tabular}{|l|l|c|c|}
\hline No. & \multicolumn{1}{|c|}{ Usia } & \multicolumn{1}{|c|}{$\begin{array}{c}\text { Jumlah } \\
\text { (orang) }\end{array}$} & $\begin{array}{c}\text { Presentae } \\
\text { (\%) }\end{array}$ \\
\hline $\mathbf{1}$ & $<15$ Tahun & - & - \\
\hline $\mathbf{2}$ & 16 Tahun -64 tahun & 21 & 70 \\
\hline $\mathbf{3}$ & $>64$ Tahun & 9 & 30 \\
\hline Jumlah & 30 & 100 \\
\hline
\end{tabular} Sumber : data primer, 2017 (diolah)

Mayoritas responden dalam penelitian ini berusia 16 tahun - 64 tahun yang termasuk ke dalam golongan produktif yaitu sebanyak 21 anggota (70\%), dan terdapat 9 anggota yang berusia lebih dari 64 tahun $(30 \%)$ termasuk kedalam katagori umur tidak produktif. Maka dapat disimpulkan bahwa potensi untuk meninngkatkan kemandirian anggota kelompok tani cukup tinggi, mengingat mayoritas anggota berada dalam katagori usia produktif.

\section{2) Jenis Kelamin}

Jenis kelamin responden yang terlibat dalam penelitian ini didominasi oleh laki-laki, bisa dilihat dalam tabel berikut ini :

Tabel 3. Karakteristik Responden Berdasarkan Jenis Kelamin

\begin{tabular}{|c|l|c|c|}
\hline No. & \multicolumn{1}{|c|}{ Jenis Kelamin } & $\begin{array}{c}\text { Jumlah } \\
\text { (orang) }\end{array}$ & $\begin{array}{c}\text { Presentase } \\
\text { (\%) }\end{array}$ \\
\hline $\mathbf{1}$ & Laki-laki & 29 & 95 \\
\hline $\mathbf{2}$ & Perempuan & 1 & 5 \\
\hline Jumlah & 30 & 100 \\
\hline
\end{tabular}

Sumber : Data primer, 2017 (diolah)

Hal ini juga menunjukkan bahwa dalam kegiatan usahatani, laki-laki lebih banyak berperan.

\section{3) Tingkat Pendidikan}

Pendidikan formal membentuk nilai bagi seseorang terutama dalam

menerima hal baru. Berikut adalah karakteristik responden berdasarkan tingkat pendidikan :

Tabel 4. Karakteristik Responden Berdasarkan Tingkat Pendidikan

\begin{tabular}{|c|l|c|c|}
\hline No. & \multicolumn{1}{|c|}{ Tingkat Pendidikan } & Jumlah (orang) & Presentase (\%) \\
\hline $\mathbf{1}$ & Tidak Tamat SD & - & - \\
\hline $\mathbf{2}$ & SD & 21 & 70 \\
\hline $\mathbf{3}$ & SMP & 4 & 13 \\
\hline $\mathbf{4}$ & SMA/Sederajat & 4 & 13 \\
\hline $\mathbf{5}$ & Sarjana & 1 & 4 \\
\hline Jumlah & 30 & 100 \\
\hline
\end{tabular}

Berdasarkan presentase tersebut tingkat pendidikan responden masih sangat rendah, lulusan Sekolah Dasar (SD) paling dominan yaitu sebanyak 21 responden $(70 \%)$. Hal ini merupakan salah satu faktor penghambat dalam pengembangan usaha tani. Sesuai pendapat Notoatmodjo (2007), bahwa tingkat pendidikan turut pula menentukan mudah atau tidaknya seseorang menyerap dan memahami

Pengaruh Kepemimpinan Ketua Kelompok Terhadap

TRI RAHAYU dan ROSDA AMALIA 
pengetahuan yang mereka peroleh, pada umumnya semakin tinggi pendidikan seseorang makin baik pula pengetahuannya.

\section{4) Luas Lahan}

Luas lahan merupakan salah satu faktor pendukung dalam meningkatkan produktifitas hasil tani yang diperoleh. Karena semakin luas lahan yang dimiliki, maka akan semakin tinggi pula produksi yang dihasilkan. Menurut Choirotunnisa
(2008), luas lahan dibagi menjadi 3 katagori yakni :

1) katagori rendah, jika luas lahan $<9.000 \mathrm{~m}^{2}$

2) Katagori sedang, jika luas lahan $9.000 m^{2}-16.000 m^{2}$

3) Dan katagori tinggi, jika luas lahan berkisar $>16.000 \mathrm{~m}^{2}$

Adapun karakteristik responden berdasarkan luas lahan adalah sebagai berikut :

Tabel 5. Karakteristik Responden Berdasarkan Luas Lahan

\begin{tabular}{|c|c|c|c|c|}
\hline No. & Luas Lahan & Kategori & Jumlah (orang) & Presentase (\%) \\
\hline 1 & $>16.000 \mathrm{~m}^{2}$ & Tinggi & 0 & 0 \\
\hline 2 & $9.000-16.000 \mathrm{~m}^{2}$ & Sedang & 5 & 17 \\
\hline 3 & $<9.000 \mathrm{~m}^{2}$ & Rendah & 25 & 83 \\
\hline \multicolumn{3}{|c|}{ Jumlah } & 30 & 100 \\
\hline
\end{tabular}

Dari presantase hasil olahan data diatas, petani di GPO Nyi-Sri dominan memiliki luas lahan yang rendah $\left(<9.000 \mathrm{~m}^{2}\right)$, yaitu sebanyak 25 orang atau 83\%. Jika mengingat luas lahan merupakan salah satu faktor penting dalam produktifitas pertanian, maka petani dituntut untuk lebih kreatif lagi agar produktifitas hasil tani yang diperoleh tidak terpaku pada luas lahan saja. Dalam kemandirian material anggota kelompok, petani dihimbau untuk dapat membudidayakan varietas-varietas lain selain daripada padi pandanwangi organik, serta melakukan kegiatan pertanian lain seperti penanganan pasca panen (pengolahan pangan, pemasaran hasil panen, dan lain-lain), serta memiliki tingkat kreativitas yang tinggi, agar seluas apapun lahan yang dimiliki dapat di manfaatkan secara baik.

\section{5) Status Kepemilikan}

Secara umum, petani memiliki lahan pertanian dengan status kepemilikan milik pribadi, akan tetapi yang tidak memiliki lahanpun bukan berarti tertutup kesempatan untuk bertani. Ada istilah dari Bahasa Sunda yang disebut gade dan maparo, dengan kata lain gade adalahh sewa lahan/tanah dari orang yang membutuhkan uang, dengan memberikan jaminan berupa lahan yang dapat digarap, tetapi sewaktu-waktu lahan tersebut dapat diambil kembali dengan syarat uang yang dipinjami sudah dikembalikan. Sedangkan maparo artinya "separuh-separuh" atau pembagian hasil garapan lahan antara orang yang memiliki lahan dengan penggarap/pengelola lahan. Adapun karakteristik responden berdasarkan status kepemilikan lahan adalah sebagai berikut:

Tabel 6. Karakteristik Responden Berdasarkan Status kepemilikan Lahan

\begin{tabular}{|l|l|c|c|}
\hline No. & Status Kepemilikan & Jumlah (orang) & Presentase (\%) \\
\hline 1 & Milik sendiri & 21 & 70 \\
\hline 2 & Milik orang lain / sewa & 9 & 30 \\
\hline \multicolumn{2}{|c|}{ Jumlah } & $\mathbf{3 0}$ & $\mathbf{1 0 0}$ \\
\hline
\end{tabular}

Sumber : data primer, 2017 (diolah)

Pengaruh Kepemimpinan Ketua Kelompok Terhadap

TRI RAHAYU dan ROSDA AMALIA

Tingkat Kemandirian Anggota Kelompok Di Gabungan

Petani Organik (Gpo) Nyi-Sri Kecamatan Cianjur

Kabupaten Cianjur 
Pada penyajian data di atas, status kepemilikan lahan di GPO Nyi-Sri relatif bagus yaitu dengan presentase $70 \%$ telah memiliki lahan pertanian sendiri atau 21 orang, sedangkan sisanya masih berstatus sewa/milik orang lain. Dengan melihat hal tersebut, potensi untuk memajukan kelompok tani sangat bagus. Dengan dibekali pengetahuan-pengetahuan dari kegiatan penyuluhan, pelatihan dan saling berbagi dengan anggota kelompok lain, diharapkan mampu mendorong anggota kelompok untuk terus menggali motivasi dan inofasi, serta kreatifitas dan inisiatif yang tinggi terhadap memajukan atau mempertahankan eksistensi kelompok tani.

\section{6) Lama Berusaha Tani}

Pengalaman usaha adalah jumlah tahun berupa pengalaman yang dilalui petani lahan sempit sebagai bagian dari proses belajar dalam kegiatan budidaya, produksi dan seluk beluk usaha dan pemasaran hasil panen dalam rangka memperoleh penghasilan. Selengkapnya berikut adalah karakteristik responden berdasarkan lama berusaha tani :

Tabel 7. Karakteristik Responden Berdasarkan Lama Berusaha Tani

\begin{tabular}{|l|l|l|c|c|}
\hline No. & Lama Berusaha Tani & Katagori & Jumlah & Persentase (\%) \\
\hline $\mathbf{1}$ & $>10$ tahun & Tinggi & 9 & 30 \\
\hline $\mathbf{2}$ & $5-10$ tahun & Sedang & 10 & 33 \\
\hline $\mathbf{3}$ & $<5$ tahun & Rendah & 11 & 37 \\
\hline Jumlah & $\mathbf{3 0}$ & $\mathbf{1 0 0}$ \\
\hline
\end{tabular}

Sumber : data primer, 2017 (diolah)

Terlihat presentase yang perbedaannya relatif sedikit. Namun petani yang termasuk ke dalam katagori tinggi menempati posisi paling bawah, yaitu $30 \%$ (9 orang), katagori sedang 33\% (10 orang) dan katagori rendah memiliki presentse yang paling tinggi yaitu 37\% (11 orang). Perbedaan tersebut tidak terlalu jauh. Akan tetapi dengan adanya 9 petani yang sudah berpengalaman, didukung oleh peran penyuluh dan pemilihan ketua kelompok yang tepat, setidaknya kepandaian, pengalaman dan kreatifitas dalam bertani yang dimiliki oleh 9 petani berpengalaman ini dapat tersalurkan dengan baik ke anggota kelompok tani yang lain. Sehingga mampu memotivasi anggota kelompok lain untuk lebih baik dan terus berinovasi, untuk meningkatkan kemandirian, produktifitas dan pendapatan petani padi pandanwangi organik.

\section{Kepemimpinan Ketua Kelompok GPO-Nyi.Sri Kecamatan Cianjur}

Kepemimpinan ketua kelompok tani merupakan sesuatu yang ditetapkan berdasarkan musyawarah, dibentuk karena suatu kelompok memerlukan sosok pimpinan yang dapat diandalkan, bisa dijadikan contoh yang baik, menginspirasi dan memotivasi anggotanya serta membawa kelompok ke arah yang lebih baik lagi. Untuk mengukur kepemimpinan ketua kelompok di GPO Nyi-Sri Kecamatan Cianjur, peneliti menetapkan pengukuran berdasarkan tiga variabel yang dikembangkan menjadi beberapa indikator. Variabel penelitian di ambil dari penelitian terdahulu milik Zakariyya (2010). Berikut adalah hasil pengukuran kepemimpinan ketua kelompok di GPO Nyi-Sri Kecamatan Cianjur berdasarkan skor rata-rata dari nilai komulatif setiap variabel : 
Tabel 8. Skor Kepemimpinan Ketua Kelompok Secara Komulatif

\begin{tabular}{|l|l|c|c|}
\hline No. & \multicolumn{1}{|c|}{ Variabel } & $\begin{array}{c}\text { Nilai } \\
\text { Rata - Rata }\end{array}$ & Kategori \\
\hline 1. & Sifat Kepemimpinan Ketua Kelompok & 4,2 & Baik \\
\hline 2. & Prilaku Kepemimpinan Ketua Kelompok & 4,28 & Sangat Baik \\
\hline 3. & Kekuasaan Kepemimpinan Ketua Kelompok & 3,63 & Baik \\
\hline \multicolumn{2}{|c|}{ Skor Rata - Rata } & 4,03 & Baik \\
\hline
\end{tabular}

Sumber : data primer, 2017 (diolah)

Skor tersebut menunjukan bahwa anggota kelompok mengakui bahwa kepemimpinan ketua kelompok di GPO Nyi-Sri Kecamatan Cianjur sudah baik.

Selain daripada itu, berikut adalah rincian indikator dari setiap variabel kepemimpinan ketua kelompok GPO Nyi-Sri Kecamatan Cianjur :

\section{1) Sifat kepemimpinan ketua kelompok \\ Sifat kepemimpinan ketua} kelompok menurut Zakariya (2014), didefinisikan sebagai karakteristik khas ketua kelompok tani yang dikaitkan dengan keberhasilan kepemimpinannya di dalam kelompok tani. Berikut adalah kepemimpinan ketua kelompok di GPONy.Sri Kecamatan Cianjur berdasarkan variabel sifat kepemimpinan ketua kelompok (tabel 9).

Tabel 9. Skor Variabel Sifat Kepemimpinan Ketua Kelompok

\begin{tabular}{|c|l|c|c|}
\hline No. & \multicolumn{1}{|c|}{ Indikator } & \multicolumn{2}{|c|}{ Responden Yang Menjawab } \\
\cline { 3 - 4 } & & $\begin{array}{c}\text { Nilai } \\
\text { Rata - Rata }\end{array}$ & Kategori \\
\hline 1. & $\begin{array}{l}\text { Pengakuan terhadap hasil kerja : kemampuan menyelesaikan } \\
\text { tugas dengan baik. }\end{array}$ & 4,43 & Sangat Baik \\
\hline 2. & $\begin{array}{l}\text { Kesediaan waktu ketua kelompok : intensitas waktu yang } \\
\text { diberikan terhadap kelompok. }\end{array}$ & 4,27 & Sangat Baik \\
\hline 3. & $\begin{array}{l}\text { Kesediaan berbagi : intensitas ketua dalam berbagi } \\
\text { (informasi, pengetahuan, keterampilan dan lain-lain). }\end{array}$ & 3,5 & Baik \\
\hline 4 & $\begin{array}{l}\text { Kepekaan sosial : peka terhadap konflik yang terjadi dalam } \\
\text { kelompok. }\end{array}$ & 3,6 & Baik \\
\hline \multicolumn{2}{|c|}{ Skor Rata - Rata } \\
\hline
\end{tabular}

Sumber : data primer, 2017 (diolah)

Sifat kepemimpinan ketua kelompok GPO Nyi-Sri Kecamatan Cianjur memperoleh nilai sebesar 4,2 (baik). Hal tersebut karena anggota kelompok mengakui bahwa ketua kelompok mempunyai sifat dan kemampuan yang baik dalam mengemban tugasnya sebagai ketua kelompok, ketua kelompok memberikan intensitas waktu dan kesediaan berbagi untuk kelompok dan punya kepekaan sosial, peka terhadap konflik yang terjadi dalam kelompok serta dapat terselesaikan dengan baik. Pada variabel sifat kepemimpinan nilai rata-rata terendah pada indikator kepekaan sosial, yaitu sebesar 3,6. Hal tersebut, mengingat usia ketua kelompok sudah masuk dalam usia lanjut (tidak produktif) yaitu 74 tahun. Sehingga ketua kelompok menjadi tidak cepat tanggap seperti pada saat masih dalam usia produktif.

\section{2) Prilaku kepemimpinan ketua kelompok}

Prilaku kepemimpinan merupakan suatu bentuk perhatian/ pengertian/kepekaan yang harus dimiliki oleh ketua kelompok, guna menjalin hubungan baik dan

Pengaruh Kepemimpinan Ketua Kelompok Terhadap

TRI RAHAYU dan ROSDA AMALIA 
memberikan kenyamanan dalam kelompok terhadap anggota-anggotanya.

Adapun prilaku kepemimpinan di GPO-

Nyi.Sri Kecamatan Cianjur meliputi :

Tabel 10. Skor Variabel Prilaku Kepemimpinan Ketua Kelompok

\begin{tabular}{|l|l|c|c|}
\hline No. & \multicolumn{1}{|c|}{ Indikator } & \multicolumn{2}{c|}{ Responden Yang Menjawab } \\
\cline { 3 - 4 } & & $\begin{array}{c}\text { Nilai } \\
\text { Rata - Rata }\end{array}$ & Kategori \\
\hline 1. & $\begin{array}{l}\text { Konsiderasi : kedekatan hubungan antara ketua dengan } \\
\text { anggota kelompok. }\end{array}$ & 4,3 & Sangat Baik \\
\hline 2. & $\begin{array}{l}\text { Pembentukan struktur : pembagian tugas dan tanggung } \\
\text { jawab sesuai potensi yang dimiliki anggota. }\end{array}$ & 4,27 & Sangat Baik \\
\hline \multicolumn{1}{|l|}{ Skor Rata - Rata } & 4,28 & Sangat Baik \\
\hline
\end{tabular}

Sumber : data primer, 2017 (diolah)

Pada penyajian data di atas, terdapat prilaku kepemimpinan ketua kelompok di GPO Nyi-Sri Kecamatan Cianjur memperoleh nilai sebesar 4,28 (sangat baik). Hal tersebut karena konsiderasi atau kedekatan hubungan antara ketua kelompok dengan anggota kelompoknya terlihat begitu hangat, kehangatan hubungan kelompok tersebut memberikan dampak yang positif, seperti pada profesionalitas dan tanggung jawab masing-masing dengan tetap mempertahankan kekeluargaan yang telah terjalin didalam kelompok, serta struktur kelompok yang terbentuk berdasarkan potensi dan kesiapan dari anggotanya tanpa ada unsur paksaan. Dari hasil penilaian yang sangat baik tersebut, maka prilaku kepemimpinan ketua kelompok seperti ini sangat baik pula untuk dipertahankan. Guna menjaga konsiderasi yang telah terjalin.

\section{3) Kekuasaan kepemimpinan ketua kelompok.}

Menurut Zakariyya (2010), kekuasaan (power) didefiniskan sebagai kapasitas mempengaruhi perilaku orang lain. Seorang pemimpin dianggap mempunyai kekuasaan sepanjang dapat terus mengendalikan dan mempengaruhi orang lain (anggotanya). Kekuasaan kepemimpinan ketua kelompok di GPONyi. Sri Kecamatan Cianjur di ukur dengan dua indikator, berikut adalah hasil pengukurannya :
Tabel 11. Skor Variabel Kekuasaan

Kepemimpinan Ketua Kelompok

\begin{tabular}{|c|c|c|c|}
\hline \multirow[t]{2}{*}{ No. } & \multirow[t]{2}{*}{ Indikator } & \multicolumn{2}{|c|}{$\begin{array}{c}\text { Responden Yang } \\
\text { Menjawab }\end{array}$} \\
\hline & & $\begin{array}{l}\text { Nilai } \\
\text { Rata - } \\
\text { Rata }\end{array}$ & Kategori \\
\hline 1. & $\begin{array}{l}\text { Kekuatan menguasai : } \\
\text { pengendalian prilaku } \\
\text { anggota. }\end{array}$ & 3,57 & Baik \\
\hline 2. & $\begin{array}{l}\text { Kekuatan } \\
\text { mempengaruhi : dapat } \\
\text { menyamakan persepsi } \\
\text { / pendapat. }\end{array}$ & 3,7 & Baik \\
\hline & Skor Rata - Rata & 3,63 & Baik \\
\hline
\end{tabular}

Skor rata-rata yang diperoleh variabel kekuasaan kepemimpinan ketua kelompok GPO Nyi-Sri Kecamatan Cianjur adalah sebesar 3,63 (baik). Skor tersebut menunjukan bahwa ketua kelompok dianggap mampu mengendalikan prilaku anggota dan menyamakan persepsi anggota. Mengingat kekuasaan kepemimpinan ketua kelompok dengan kekuatan mengendalikan dan mempengaruhi anggotanya cenderung dapat memberikan dampak yang besar bagi kelangsungan hidup kelompok dan menjaga profesionalitas kelompok agar tetap produktif. Akan tetapi dari dua indikator diatas, variabel kekuasaan kelompok belum termasuk kedalam kategori sangat baik. Karena seperti yang sudah dijelaskan sebelumnya, bahwa usia ketua kelompok sudah termasuk kedalam usia lanjut. Sehingga terjadi penurunan

Pengaruh Kepemimpinan Ketua Kelompok Terhadap

TRI RAHAYU dan ROSDA AMALIA 
peroduktivitasnya sebagai ketua kelompok. Terlebih untuk mengatasi keluhan anggota tersebut, GPO Nyi-Sri sedang dalam proses pemekaran kelompok, dan merencanakan struktur organigram baru. Sehingga interaksi yang terjadi pada saat itu kurang.

Berdasarkan ketiga variabel tersebut kepemimpinan ketua kelompok GPO Nyi-Sri Kecamatan Cianjur di nilai sudah baik. Kepemimpinan yang baik merupakan modal untuk keberlanjutan kelompok. Dengan berjalannya kepemimpinan di kelompok tani, maka akan dimungkinkan kelompok tani tersebut mencapai kemandirian, kemandirian anggota kelompok adalah tingkat keberhasilan kelompok untuk mencapai tujuannya.

Dengan kepemimpinan ketua kelompok yang telah ditetapkan yaitu bapak. Ajan Suparjan. Sejauh ini pencapaian tujuan yang telah diraih oleh GPO Nyi-Sri Kecamatan Cianjur sudah sangat banyak, seperti : anggota GPO Nyi-Sri semakin pertambahan, mampu mempertahankan eksistensi pertanian organik, telah dipercaya untuk mendapat bantuan (berupa dana, alsintan, dan perbaikan akses/jalan transportasi), amanah dalam alokasi pendanaan yang diberikan pemerintah, mampu mengelola varietas unggul lain selain pandanwangi organik (pandan putri, sariak layung, singkong dan macam-macam tanaman sayuran), mampu melakukan packaging sendiri serta pemasaran baik dilakukan atas nama kelompok, pribadi maupun kerjasama dengan penyuluh/dinas pertanian Cianjur, menjadi salah satu pusat penelitian dari berbagai universitas dan kunjungan turis-turis luar negri sebagai kelompok pelestari padi pandanwangi organik dan lain sebagainya. Berdasarkan hasil wawancara, anggota kelompok sangat mengapresiasi atas kepemimpinan yang diterapkan oleh ketua kelompok GPO Nyi-Sri Kecamatan Cianjur. Dengan pencapaian tujuan yang sudah sekian banyak tersebut, anggota mengakui kepemimpin yang diterapkan ketua kelompok GPO Nyi-Sri Kecamatan Cianjur sudah baik.

\section{Tingkat Kemandirian Anggota Kelompok GPO Nyi-Sri Kecamatan Cianjur}

Sebagaimana yang dikemukakan oleh Sumardjo dalam Lestari Mugi (2011), bahwa kemandirian petani adalah kemampuan untuk mengambil keputusan sendiri secara tepat. Kekuatan sendiri yang didorong oleh motivasinya, untuk meningkatkan kualitas kehidupannya, yang juga ditandai adanya inisiatif petani untuk melihat kesempatan, memilih alternatif (kreatif) dan memutuskan pilihan yang terbaik bagi peranannya dalam masyarakat. Serta berusaha meraih kesempatan dengan segala kemampuan yang telah dan perlu dimilikinya. Untuk mengukur tingkat kemandirian anggota kelompok di GPO Nyi-Sri Kecamatan Cianjur, peneliti membatasi pada lima variabel yang dikembangkan menjadi beberapa indikator. Berikut adalah hasil penilaian dari setiap variabel :

Tabel 12. Skor Tingkat Kemandirian Anggota Kelompok Tani GPO Nyi-Sri Kecamatan Cianjur Secara

\begin{tabular}{|l|l|c|c|}
\multicolumn{1}{|c|}{ Komulatif } & \multicolumn{2}{c|}{ Responden Yang Menjawab } \\
\cline { 3 - 4 } & & Nilai Rata-rata & Kategori \\
\hline No. & & 4,05 & Baik \\
\hline 2. & Kemampuan anggota kelompok tani & 4,52 & Sangat Baik \\
\hline 3. & Dukungan moril lingkungan sosial / internal & 3,04 & Cukup \\
\hline 4. & Dukungan moril/materil dari pihak luar / eksternal & 4,18 & Baik \\
\hline 5. & Kinerja penyuluh & 4,45 & Sangat Baik \\
\hline \multicolumn{2}{|c|}{ Skor Rata-Rata } & 4,05 & Baik \\
\hline
\end{tabular}

Pengaruh Kepemimpinan Ketua Kelompok Terhadap

TRI RAHAYU dan ROSDA AMALIA

Tingkat Kemandirian Anggota Kelompok Di Gabungan

Petani Organik (Gpo) Nyi-Sri Kecamatan Cianjur

Kabupaten Cianjur 
Secara komulatif, bisa dilihat pada data yang disajikan pada tabel dan grafik di atas. Perolehan total skor tingkat kemandirian anggota kelompok GPO Nyi-Sri Kecamatan Cianjur adalah sebesar 4,05. Artinya GPO Nyi-Sri Kecamatan Cianjur memiliki tingkat kemandirian anggota kelompok yang baik.

Selain daripada itu, berikut adalah rincian indikator dari lima variabel tingkat kemandirian anggota kelompok GPO Nyi-Sri Kecamatan Cianjur :

\section{Kemampuan kelompok tani}

anggota

Kemampuan (abilities) merupakan kapasitas seseorang dalam kegiatan atau tugas yang akan sikerjakan. Kemampuan anggota kelompok tani di GPO Ny-Sri Kecamatan Cianjur dibatasi pada tiga indikator, yaitu sebagai berikut (tabel 13) :

Tabel 13. Skor Variabel Kemampuan Anggota Kelompok Tani

\begin{tabular}{|l|l|c|c|}
\hline \multirow{2}{*}{ No. } & \multicolumn{1}{|c|}{ Indikator } & \multicolumn{2}{c|}{ Responden Yang Menjawab } \\
\cline { 3 - 4 } & & $\begin{array}{c}\text { Nilai } \\
\text { Rata - Rata }\end{array}$ & Kategori \\
\hline 1. & $\begin{array}{l}\text { Kemampuan teknis : kemampuan melakukan pembagian } \\
\text { tugas sesuai dengan tupoksinya. }\end{array}$ & 3,93 & Baik \\
\hline 2. & kemampuan managerial : bertanggungjawab terhadap tugas. & 3,7 & Baik \\
\hline 3. & kemampuan sosial : keefektifan kelompok & 4,53 & Sangat Baik \\
\hline \multicolumn{2}{|r|}{ Skor Rata - Rata } & 4,05 & Baik \\
\hline
\end{tabular}

Sumber : data primer, 2017 (diolah)

Kemampuan anggota kelompok GPO Nyi-Sri Kecamatan Cianjur memperoleh nilai sebesar 4,05. Maka dapat diartikan bahwa anggota kelompok mempunyai kemampuan yang baik, seperti dalam kemampuan teknis (kemampuan melakukan pembagian tugas), kemampuan managerial (kemampuan bertanggung jawab terhadap tugas masing-masing) dan kemampuan sosial (keefektifan komunikasi kelompok). Namun, kiranya perlu ditingkatkan pada indikator kemampuan tekniks dan kemampuan managerial agar dapat menyamakan nilai dengan kemampuan sosial. Dalam upayanya bisa berupa mengikuti pelatihanpelatihan yang ada kaitannya dengan indikator tersebut. Agar lebih jelas

\section{Dukungan moril lingkungan sosial / internal}

Adapun indikator dari variabel dukungan moril lingkungan sosial adalah sebagai berikut :

Tabel 14. Skor Variabel Dukungan Moril Lingkungan Sosial / Internal

\begin{tabular}{|l|l|c|c|}
\hline \multirow{2}{*}{ No. } & \multicolumn{1}{|c|}{ Indikator } & \multicolumn{2}{c|}{ Responden Yang Menjawab } \\
\cline { 3 - 4 } & & $\begin{array}{c}\text { Nilai } \\
\text { Rata - Rata }\end{array}$ & Kategori \\
\hline 1. & Dukungan tokoh masyarakat : dukungan aparat setempat. & 4,73 & Sangat Baik \\
\hline 2. & Dukungan masyarakat setempat.. & 4,56 & Sangat Baik \\
\hline 3. & $\begin{array}{l}\text { Dukungan anggota kelompok tani : totalitas sebagai anggota } \\
\text { kelompok. }\end{array}$ & 4,26 & Sangat Baik \\
\hline \multicolumn{2}{|c|}{ Skor Rata - Rata } & 4,52 & Sangat Baik \\
\hline
\end{tabular}

Sumber : data primer, 2017 (diolah)

GPO Nyi-Sri Kecamatan Cianjur memiliki dukungan moral lingkungan sosial yang sangat baik, yaitu dengan perolehan nilai sebesar 4,52. Hal tersebut karena GPO Nyi-Sri Kecamatan Cianjur mendapat dukungan yang sangat baik dari tokoh

Pengaruh Kepemimpinan Ketua Kelompok Terhadap 
masyarakat (aparat setempat), masyarakat setempat dan dukungan dari anggota kelompok itu sendiri (totalitas sebagai anggota kelompok). Berdasarkan hasil wawancara penelitian dan penilaian tersebut, GPO Nyi-Sri Kecamatan Cianjur merupakan kelompok pelestari pertanian organik, terutama padi pandanwangi organik. Yang telah mendukung pola hidup sehat dan menjaga kesuburan tanah untuk masa yang akan datang, serta mempertahankan dan mengangkat varietas yang menjadi unggulan di Kabupaten Cianjur. Maka dari itu, GPO Nyi-Sri Kecamatan Cianjur mendapat dukungan yang sangat baik dari berbagai pihak terutama tokoh masyarakat dengan masyarakatnya dan anggota kelompok GPO Nyi-Sri Kecamatan Cianjur itu sendiri.

\section{Dukungan moral dari pihak luar / eksternal}

Dukungan moral dan materil yaitu suatu bentuk dorongan positif yang diberikan berupa bantuan (bisa berupa dana dan benda), yang dapat menunjang keberhasilan dan keberlanjutan kegiatan kelompok tani. Adapun kemandirian anggota kelompok berdasarkan variabel dukungan moral dan materil dari pihak luar dibatasi pada tiga indikator, yaitu sebagai berikut :

Tabel 15. Skor Variabel Dukungan Dari Pihak Luar / Eksternal

\begin{tabular}{|l|l|c|c|}
\hline \multirow{2}{*}{ No. } & \multicolumn{1}{|c|}{ Indikator } & \multicolumn{2}{|c|}{ Responden Yang Menjawab } \\
\cline { 3 - 4 } & & \multicolumn{1}{|c|}{$\begin{array}{c}\text { Nilai } \\
\text { Rata - Rata }\end{array}$} & Kategori \\
\hline 1. & Dukungan swasta : bantuan perusahaan. & 2,2 & Buruk \\
\hline 2. & $\begin{array}{l}\text { Dukungan Pemerintah : bantuan dari dinas / instansi } \\
\text { terkait. }\end{array}$ & 4,56 & Buruk \\
\hline 3. & Dukungan LSM : kelompok wirausaha. & 2,36 & Cukup \\
\hline \multicolumn{1}{|l|}{ Skor Rata - Rata } & 3,04 & Baik \\
\hline
\end{tabular}

Sumber : data primer, 2017 (diolah)

GPO Nyi-Sri Kecamatan Cianjur memperoleh dukungan moral/materil yang cukup baik, yaitu dengan perolehan nilai sebesar 3,04 (tabel 20). Hal tersebut dikarenakan dukungan penuh hanya diberikan oleh pemerintah seperti Dinas terkait (Dinas Pertanian). Dukungan tersebut berupa bantuan dana dan benda yang menunjang dalam keberhasilan kegiatan kelompok, seperti bantuan akses jalan untuk memudahkan dalam transportasi, bantuan alsintan (alat mesin pertanian) untuk memudahkan dalam proses produksi, pasca panen dan packaging, bantuan pengadaan peternakan untuk mempermudah dalam pembuatan pupuk dan menambah ragam kegiatan pertanian dan bantuan modal lainnya untuk membantu kegiatan-kegiatan pertanian organik dan lain sebagainya. Akan tetapi bantuan-bantuan tersebut tidak lantas membuat anggota GPO NyiSri Kecamatan Cinjur menjadi ketergantungan. Berdasarkan hasil wawancara, anggota kelompok relatif gigih dalam mempertahankan pertanian organik. Khususnya padi pandanwangi organik yang merupakan ciri khas dari Kabupaten Cianjur.

\section{Kinerja penyuluh}

Kinerja penyuluh merupakan suatu cerminan dari pelaksanaan tugas penyuluh dalam proses penyuluhan pada satu kurun waktu tertentu. Kinerja penyuluh merupakan suatu kajian seberapa besar tingkat kepandaian/kekreatifan penyuluh dalam menyampaikan suatu materi (topik/konten), karena dengan didampingi penyuluh yang kompeten cenderung dapat membantu anggota

Pengaruh Kepemimpinan Ketua Kelompok Terhadap

TRI RAHAYU dan ROSDA AMALIA 
kelompok menuju kemandirian. Adapun penilaian indikator dari variabel kinerja penyuluh di GPO Nyi-Sri Kecamatan

Cianjur adalah sebagai berikut :

Tabel 16. Skor Variabel Kinerja Penyuluh

\begin{tabular}{|l|l|c|c|}
\hline \multirow{2}{*}{ No. } & \multicolumn{1}{|c|}{ Indikator } & \multicolumn{2}{c|}{ Responden Yang Menjawab } \\
\cline { 3 - 4 } & & $\begin{array}{c}\text { Nilai } \\
\text { Rata - Rata }\end{array}$ & Kategori \\
\hline 1. & Kesesuaian materi : topik / konten yang disampaikan. & 4,73 & Baik \\
\hline 2. & Kesesuaian metode : cara penyampaian. & 4,36 & Sangat Baik \\
\hline 3. & Kompetensi penyuluh : keahlian dalam menekuni profesi. & 3,46 & Baik \\
\hline \multicolumn{2}{r}{ Skor Rata - Rata } & 4,18 & Baik \\
\hline
\end{tabular}

Sumber : data primer, 2017 (diolah)

Kinerja penyuluh di GPO Nyi-Sri Kecamatan Cianjur memperoleh penilaian yang baik, yaitu dengan nilai 4,18. Maka dapat diartikan bahwa kinerja penyuluh dalam penyampaian topik/konten (kesesuaian materi), cara penyampaian (kesesuian metode) dan keahlian dalam menekuni profesinya (kompetensi penyuluh) dianggap sudah baik. Akan tetapi indikator kompetensi penyuluh mendapat nilai terendah diantara indikator lain, hal tersebut dikarenakan tugas dan tanggung jawab penyuluh yang tidak hanya membina kelompok di GPO NyiSri Kecamatan Cianjur saja. Rendahnya kompetensi penyuluh bisa menjadi salah satu pemicu rendahnya nilai kemampuan teknis dan kemampuan managerial anggota kelompok di GPO Nyi-Sri Kecamatan Cianjur, karena kurangnya keahlian dalam menekuni profesinya sebagai penyuluh atau kurang memberikan pelatihan/pembinaan kepada anggota kelompok GPO Nyi-Sri.

\section{Inisiatif kemandirian}

Variabel inisiatif kemandirian dilihat dari tiga indikator, hasil penelitian tentang variabel tersebut dilihat pada tabel 17. Berikut adalah rincian indikator dari variabel inisiatif kemandirian anggota kelompok di GPO Nyi-Sri Kecamatan Cianjur :

Tabel 17. Skor Variabel Inisiatif Kemandirian

\begin{tabular}{|l|l|c|c|}
\hline No. & \multicolumn{1}{|c|}{ Indikator } & \multicolumn{2}{c|}{ Responden Yang Menjawab } \\
\cline { 3 - 4 } & & $\begin{array}{c}\text { Nilai } \\
\text { Rata - Rata }\end{array}$ & Kategori \\
\hline 1. & $\begin{array}{l}\text { Kemandirian intelektual : penyelesaian konflik dalam } \\
\text { kelompok. }\end{array}$ & 4,13 & Baik \\
\hline 2. & $\begin{array}{l}\text { Kemandirian pembinaan : upaya menggali potensi (kreatifitas } \\
\text { dan inovatif). }\end{array}$ & 4,73 & Sangat Baik \\
\hline 3. & $\begin{array}{l}\text { Kemandirian material : mengelola varietas unggulan dan atau } \\
\text { SDA lainnya. }\end{array}$ & 4,5 & Sangat Baik \\
\hline \multicolumn{1}{|c|}{ Skor Rata - Rata } & 4,45 & Sangat Baik \\
\hline
\end{tabular}

Sumber : data primer, 2017 (diolah)

Variabel inisiatif kemandirian anggota kelompok di GPO Nyi-Sri Kecamatan Cianjur dinilai sangat baik, dengan perolehan skor rata-rata sebesar 4,45 (tabel 22). Artinya, anggota kelompok sudah sangat baik dalam inisiatif kemandirian intelektual (penyelesaian konflik dalam kelompok), inisiatif kemandirian pembinaan (upaya menggali potensi/kreatif dan inovatif) dan inisiatif kemandirian material (dapat mengelola

Pengaruh Kepemimpinan Ketua Kelompok Terhadap 
varietas unggulan/SDA lain : padi pandan putri, sariak layung, dll).

Kemandirian yang telah terbentuk di GPO Nyi-Sri Kecamatan Cianjur merupakan hasil dari kegigihan masing-masing anggota terhadap komitmennya sebagai petani organik. Bukti kemandirian dari GPO Nyi-Sri Kecamatan Cianjur diantaranya :

1. Kemandirian intelektual : anggota mampu berkomunikasi dan menyelesaikan konflik dengan baik. Baik itu konflik dalam kelompok maupun konflik individu.

2. Kemandirian pembinaan : kelompok mampu menggali potensi (kreatif dan inovatif). Secara perlahan interaksi dalam kelompok akan melahirkan kreatifitas. Contohnya seperti inovasi pupuk alami yang menggunakan air beras..

3. Kemandirian material : kelompok mampu membudidayakan varietas unggul lain seperti : pandan puteri, sariak layung, padi hitam biasa dan ketan hitam, macam-macam sayuran organik dan melakukan pengolahan pasca panen (pembuatan opak singkong dan opak gender padi hitam), mampu mengelola peternakan dan lain sebagainya.

Kemandirian bukan berarti mampu hidup sendiri, tetapi mandiri dalam pengambilan keputusan. Yakni memiliki kemampuan untuk memilih dan berani untuk menolak segala bentuk dan kerjasama yang tidak menguntungkan. Penilaian terhadap kemandirian anggota kelompok di GPO Nyi-Sri Kecamatan Cianjur bisa terlihat berdasarkan kelima variabel. Selain itu jika dilihat secara langsung, kondisi kelompok berjalan begitu hangat, seperti bersinergisnya antara anggota dengan pengurus, begitupun dengan penyuluhnya. Tampak kompak dan harmonis, terlihat saling memberikan motivasi satu sama lain demi kemajuan kelompok. Terbukti dari eksistensi kelompok yang mampu bertahan dari Tahun 2009 sampai saat ini. Anggota mampu bertahan dalam kelompok serta menjaga komitmen terhadap pemasaran yang dibantu oleh pemerintah, hal tersebut berkat kepemimpinan yang diterapkan oleh ketua kelompok GPO Nyi-Sri Kecamatan Cianjur. Penyusunan struktur organisasi yang sesuai potensi anggota, kerjasama dan totalitas yang baik dari masing-masing anggota untuk melaksanakan komitmennya sebagai petani organik. Sehingga dapat memajukan kelompok dan melahirkan kemandirian anggota kelompok yang baik, kreatif dan tidak saling mengandalkan, mereka menyadari terhadap tugas dan fungsi masing-masing. Dari hasil penelitian dilapangan dapat dicermati, apabila kepemimpinan ketua kelompoknya berjalan dengan baik maka akan diikuti dengan kemandirian anggota kelompok yang baik pula.

\section{Hubungan Kepemimpinan Ketua Kelompok Dengan Tingkat Kemandirian Anggota Kelompok GPO Nyi-Sri Kecamatan Cianjur}

Kepemimpinan ketua kelompok merupakan salah satu faktor penting yang mendorong berjalannya suatu kelompok agar terwujudnya efektifitas. Menurut Mulyadi dan Rivai (2012), kepemimpinan harus berfungsi secara baik untuk mewujudkan interaksi sosial sebuah kelompok atau organisasi. Dengan berjalannya kepemimpinan di kelompok tani, maka akan dimungkinkan kelompok tani tersebut mencapai kemandirian, kemandirian anggota kelompok adalah tingkat keberhasilan kelompok untuk 
mencapai tujuannya. Begitupun yang terjadi di GPO Nyi-Sri Kecamatan Cianjur. Dalam gerak dan kekuatan pada proses menuju kemandirian anggota kelompok, GPO Nyi-Sri Kecamatan Cianjur tidak terlepas dari kerjasama yang kuat dan peran ketua kelompok yang merupakan pimpinan, yang mempunyai kekuatan untuk mengendalikan dan mempengaruhi anggota kelompok dan kegiatan didalamnya.
Adapun hubungan antara kepemimpinan ketua kelompok dengan tingkat kemandirian anggota kelompok di GPO Nyi-Sri Kecamatan Cianjur, diuji melalui analisis statistik yaitu uji korelasi pearson product moment (menggunakan SPSS 18) dengan tingkat kepercayaan $\alpha=0,05$. Maka korelasi dari kedua variabel dapat dikatakan signifikan apabila nilai sig $<\alpha$. Berikut adalah hasil pengujian korelasi pearson product moment (tabel 23) :

Tabel 18. Output Korelasi Pearson Product Moment

\begin{tabular}{|ll|r|r|}
\hline \multicolumn{3}{|c|}{ Correlations } \\
\hline & \multicolumn{1}{|c|}{ TOTAL_X } & \multicolumn{1}{|c|}{ TOTAL_Y } \\
\hline TOTAL_X & Pearson Correlation & 1 & $\mathbf{7 8 7}^{* *}$ \\
& Sig. (1-tailed) & & $\mathbf{0 0 0}$ \\
& $\mathrm{N}$ & 30 & 30 \\
\hline TOTAL_Y & Pearson Correlation & $\mathbf{7 8 7 ^ { * * }}$ & 1 \\
& Sig. (1-tailed) & $\mathbf{0 0 0}$ & 30 \\
$\mathrm{~N}$ & 30 & 30 \\
\hline
\end{tabular}

**. Correlation is significant at the 0.01 level (1-tailed).

Sumber : data primer, 2017 (diolah)

Nilai pearson correlation (R) yang diperoleh adalah sebesar 0,787. Maka dapat diartikan bahwa terdapat hubungan yang sangat kuat antara kepemimpinan ketua kelompok $(\mathrm{X})$ dengan tingkat kemandirian anggota kelompok GPO Nyi-Sri Kecamatan Cianjur (Y). Sebagaimana yang telah dijelaskan sebelumnya terkait interpretasi nilai $\mathrm{R}$, jika nilai $\mathrm{R}$ mendekati angka 1 maka hubungannya semakin kuat dan angka 1 merupakan nilai sempurna, begitupun sebaliknya. Sedangkan arah hubungan dari keduanya adalah positif, artinya semakin tinggi tingkat kepemimpinan ketua kelompok (X) maka akan semakin meningkat pula tingkat kemandirian anggota kelompok GPO Nyi-Sri Kecamatan Cianjur (Y). Kemudian nilai dari Sig. (1-tailed) yang menunjukan signifikansi hubungan antara kepemimpinan ketua kelompok (X) dan tingkat kemandirian anggota kelompok GPO Nyi-Sri Kecamatan Cianjur (Y), nilai yang diperoleh adalah 0,000. Berdasarkan itu, nilai sig $0,000<0,05$ artinya dapat dinyatakan bahwa korelasi kedua variabel tersebut signifikan.

Dari hasil penelitian, dapat diamati bahwa kepemimpinan ketua kelompok sangat erat hubungannya dengan tingkat kemandirian anggota kelompok GPO Nyi-Sri Kecamatan Cianjur. Hasil penelitian ini sangat selaras dengan pendapat Bass dalam Unang (2005) yang menyatakan bahwa pemimpin (ketua kelompok) adalah agen perubahseseorang yang dapat lebih mempengaruhi. Kepemimpinan merupakan suatu interaksi antara dua orang atau lebih anggota yang sering mencakup penyusunan struktur atau pengubahan stuktur dari situasi dan persepsi dan harapan para anggota. Oleh karenanya kepemimpinan akan muncul ketika satu anggota kelompok (ketua kelompok) dapat memotivasi atau memberi kompetensi pada yang lain dalam kelompok.

Ketua kelompok dengan kepemimpinannya yang tergolong baik,

Pengaruh Kepemimpinan Ketua Kelompok Terhadap

Tingkat Kemandirian Anggota Kelompok Di Gabungan

TRI RAHAYU dan ROSDA AMALIA

Petani Organik (Gpo) Nyi-Sri Kecamatan Cianjur

Kabupaten Cianjur 
akan memberikan peluang yang sangat besar untuk tercapainya kemandirian anggota dalam kelompok yang dipimpinnya tersebut. Hal ini dimungkinkan karena ketua kelompok yang kepemimpinannya baik, memiliki kemampuan yang lebih baik atau lebih tinggi di dalam mempengaruhi anggota lainnya. Terutama untuk mencapai tingkat kemandirian anggota kelompok. Hal ini termasuk di dalam menyusun struktur atau pengubahan stuktur yang diselaraskan dengan persepsi dan harapan para anggota untuk mencapai keberhasilan usaha taninya, terutama usaha tani padi pandanwangi organik, yang merupakan varietas unggul lokal.

Sejalan dengan Zakariyya (2010), Fungsi kelompok tani akan berjalan baik apabila pemimpin / ketua kelompok tani mampu menggerakkan anggota kelompok tani untuk melakukan sesuatu untuk mencapai tujuan. Dalam menggerakkan anggota, kepemimpinan ketua kelompok tani sangat menentukan sikap anggota kelompok terhadap perintah maupun informasi yang diberikan. Kesesuaian keadaan dan kondisi kelompok tani dengan kepemimpinan ketua kelompok tani akan mewujudkan kemandirian anggota kelompok tani yang dibinanya.

\section{Pengaruh Kepemimpinan Ketua Kelompok Terhadap Tingkat Kemandirian Anggota Kelompok GPO Nyi-Sri Kecamatan Cianjur}

Pada hasil analisis regresi, akan dijelaskan besar kontribusi variabel kepemimpinan ketua kelompok (X) terhadap variabel tingkat kemandirian anggota kelompok GPO Nyi-Sri Kecamatan Cianjur (Y), serta seberapa signifikan pengaruh antara variabel $\mathrm{X}$ terhadap variabel Y. Berikut adalah hasil pengolahan analisis regresi linier sederhana dengan menggunakan SPSS 18

Tabel 19. Output Regresi Linier Sederhana (Model Summary)

\begin{tabular}{|c|c|c|c|c|}
\hline \multicolumn{5}{|c|}{ Model Summary } \\
\hline Model & $\mathrm{R}$ & R Square & Adjusted R Square & Std. Error of the Estimate \\
\hline 1 &, $787^{a}$ & 619 & 605 & 3,009 \\
\hline
\end{tabular}

a. Predictors: (Constant), TOTAL_X

Sumber : data primer, 2017 (diolah)

Pada tabel 24, terdapat nilai R Square yang diperoleh adalah sebesar 0,619 atau 61,9\%. Artinya besarnya kontribusi kepemimpinan ketua kelompok (X), terhadap tingkat kemandirian anggota kelompok GPO Nyi-Sri Kecamatan Cianjur (Y) yang dapat dijelaskan pada model ini adalah sebesar $61,9 \%$. Sedangkan 38,1\% dijelaskan oleh faktor lain diluar dari model penelitian.

Kemudian untuk mengetahui apakah variabel kepemimpinan ketua kelompok berpengaruh signifikan atau tidak terhadap tingkat kemandirian anggota kelompok GPO Nyi-Sri Kecamatan Cianjur, dilakukan uji t. Apabila $\mathrm{t}$ hitung $>\mathrm{t}$ tabel maka dapat dinyatakan bahwa variabel kepemimpinan ketua kelompok (X) berpengaruh signifikan terhadap tingkat kemandirian anggota kelompok GPO Nyi-Sri Kecamatan Cianjur (Y), begitupun sebaliknya. Atau bisa dilihat dari perbandingan antara nilai $\alpha$ dengan nilai sig. Apabila nilai $\alpha>$ nilai sig, maka pengaruh keduanya signifikan. Begitupun sebaliknya. Berikut dijelaskan pada tabel 20 : 
Tabel 20. Output Regresi Linier Sederhana (Coefficients)

\begin{tabular}{|c|c|c|c|c|c|c|}
\hline \multicolumn{7}{|c|}{ Coefficients $^{a}$} \\
\hline \multirow{2}{*}{\multicolumn{2}{|c|}{ Model }} & \multicolumn{2}{|c|}{ Unstandardized Coefficients } & $\begin{array}{l}\text { Standardized } \\
\text { Coefficients }\end{array}$ & \multirow[b]{2}{*}{$\mathrm{T}$} & \multirow[b]{2}{*}{ Sig. } \\
\hline & & B & Std. Error & Beta & & \\
\hline \multirow[t]{2}{*}{1} & (Constant) & 34,500 & 5,228 & & 6,599 & ,000 \\
\hline & TOTAL_X & 1,000 & ,148 & ,787 & 6,745 & ,000 \\
\hline
\end{tabular}

Untuk model persamaan regresi linier sederhana adalah $\mathrm{Y}=\mathrm{a}+\mathrm{bX}$. Y adalah variabel dependen (tingkat kemandirian anggota kelompok GPO Nyi-Sri Kecamatana Cianjur). Dari hasil penelitian tersebut diperoleh nilai a atau konstanta sebesar 34,500 dan kooefisien X sebesar 1,000 (tabel 25). Maka diperoleh model persamaan regresinya adalah $\mathrm{Y}=\mathrm{a}+\mathrm{bX}$ menjadi $Y=34,500+1,000$

Hipotesis :

1. Ho : kepemimpinan ketua kelompok tidak berpengaruh signifikan terhadap tingkat kemandirian anggota kelompok GPO Nyi-Sri Kecamatan Cianjur.

2. $\mathrm{Hi}$ : kepemimpinan ketua kelompok berpengaruh signifikan terhadap tingkat kemandirian anggota kelompok GPO Nyi-Sri Kecamatan Cianjur.

Dasar pengambilan keputusan : $\alpha: 0,05 \quad$ T tabel : 1,697

1) Jika nilai sig $>\alpha$ atau t hitung $<$ t tabel, maka Ho diterima.

2) Jika nilai sig $<\alpha$ atau t hitung $>$ t tabel maka Ho ditolak dan Hi diterima.

\section{Keputusan :}

Pada tabel 25, terdapat nilai sig variabel $\mathrm{X}$ sebesar $0,000<0,05(\alpha)$. Dan atau $\mathrm{t}$ hitung sebesar 6,745 > 1,697 (t tabel). Maka Ho ditolak dan Hi diterima.
Artinya signifikan pengaruh kepemimpinan ketua kelompok (X) terhadap tingkat kemandirian anggota kelompok GPO Nyi-Sri Kecamatan Cianjur (Y).

Sejalan dengan pendapat Utama (2011), kepemimpinan berperan sebagai orang yang dapat mempengaruhi, mengarahkan, menggerakkan dan mengelola kelompok guna mencapai tujuan yang telah disepakati bersama. Keefektifan kepemimpinan ketua kelompok erat kaitannya dengan keberlanjutan kelompok dalam mencapai tujuan bersama, serta untuk mencapai kemandirian anggota kelompok.

\section{KESIMPULAN DAN SARAN}

\section{Kesimpulan}

Kesimpulan hasil penelitian pengaruh kepemimpinan ketua kelompok terhadap tingkat kemandirian anggota kelompok GPO Ny.Sri Kecamatan Cianjur :

1. Kepemimpinan ketua kelompok GPO Nyi-Sri Kecamatan Cianjur berdasarkan tiga variabel memperoleh skor rata - rata sebesar 4,03 (skala 1-5). Skor tersebut menunjukkan bahwa kepemimpinan ketua kelompok di nilai baik oleh anggota kelompok GPO Nyi-Sri Kecamatan Cianjur.

2. Tingkat kemandirian anggota kelompok GPO Nyi-Sri Kecamatan Cianjur berdasarkan 
lima indikator, memperoleh skor rata - rata sebesar 4,05 (skala 1-5), maka dapat disimpulkan bahwa tingkat kemandirian anggota kelompok GPO Nyi-Sri Kecamatan Cianjur dinyatakan baik.

3. Penelitian tentang pengaruh kepemimpinan ketua kelompok terhadap tingkat kemandirian anggota kelompok GPO Nyi-Sri Kecamatan Cianjur mendapat hasil yang signifikan. Dari hasil pengolahan data menggunakan analisis statistik korelasi pearson product momentdeganSPSS 18, menunjukkan nilai korelasi atau hubungan antara variabel kepemimpinan ketua kelompok dengan tingkat kemandirian anggota kelompok GPO Nyi-Sri Kecamatan Cianjur adalah sebesar 0,787. Skor tersebut menunjukkan bahwa hubungan keduanya sangat kuat. Selain daripada itu,untuk mengetahui pengaruh kepemimpinan ketua kelompok terhadap tingkat kemandirian anggota kelompok yaitu menggunakan analisis regresi linier sederhana dengan SPSS 18, yang menunjukan nilai sig $<\alpha$ dan atau thitung $>\mathrm{t}$ tabel maka Ho ditolak dan Hi diterima begitupun sebaliknya. Dari hasil analisis regresi linier sederhana menunjukan nilai sig $0,000<0,05$ $(\alpha)$ dan atau nilai t hitung sebesar $6,745>1,697$ (t tabel). Hasil analisis tersebut menunjukkan bahwa terdapat pengaruh yang signifikan antara kepemimpinan ketua kelompok terhadap tingkat kemandirian anggota kelompok GPO Nyi-Sri Kecamatan Cianjur.

Saran

Berdasarkan kesimpulan tersebut, disarankan sebagai berikut :
1. Bagi dinas terkait :

a. Terus melakukan pengawasan terhadap kelompok tani organik.

b. Menambah ragam kegiatan :

1) Memberikan penyuluhan tentang dinamika kelompok, untuk menunjang tingkat kemandirian dan keeratan hubungan dalam kelompok.

2) Mengadakan program pelatihan yang sesuai dengan kebutuhan petani seperti : program penanaman macam - macam bibit (sayuran, bunga dan tanaman lainnya) dan diikut sertakan dalam kesempatan pameran pertanian agar progresnya dapat terus meningkat. serta dapat menambah motivasi dan meningkatkan kemandirian anggota kelompok GPO Nyi-Sri Kecamatan Cianjur.

c. Memberikan jaminan harga terhadap petani organik, sebagai stimulus agar pertanian organik dapat terus bertahan.

d. Menghimpun dukungan luar untuk prmbangunan dan pengembangan pertanian organik seperti : membantu pemasaran, pengadaan alsintan (alat dan mesin pertanian), 
penyediaan pupuk dan lain sebagainya.

2. GPO Ny. Sri Kecamatan Cianjur :

a. Merangkul petani muda sebagai generasi penerus karena banyak petani yang sudah masuk ke dalam kategori usia tidak produktif.

b. Untuk memaksimalkan kepemimpinan, tingkat kemandirian dan produktifitas anggota kelompok, disarankan untuk melakukan penyegaran keanggotaan.

kemandirian anggota
kelompok tani, pengaruh
kepemimpi
nan ketua kelompok
terhadap.

\section{DAFTAR PUSTAKA}

Choirotunnisa, 2008. Hubungan Karakteristik Sosial Ekomi Petani Dengan Tingkat Penerapan Model Pengelolaa Pengelolaan Tanaman

Hasan, I. 2009. Pokok-Pokok Materi Statistike 1 (Statistik Deskriptif). PT.Bumi Aksara. Jakarta.

Hendriyadi Barsah. 2014. Situational Leaderhip Model Hersey and Blanchardhttps://www.academia.e du/6061938/Situational Leadersh ip Hersey - Blanchard. diunduh pada tanggal 11-02-2017 jam 17.29

Lungan, R. 2006. Aplikasi Statistika dan Hitung Peluang. Penerbit Graha Ilmu. Yogyakarta.

Mugi Lestari. 2012. Metode penelitian . http://repository.ipb.ac.id/jspui/b itstream/ c. Untuk meningkatkan transfaransi dalam kepengurusan, guna menjaga kekompakan kelompok.

d. Pertahankan profesionalitas dan kekompakan yang terjalin dalam kelompok.

3. Mahasiswa :

Untuk melakukan penelitian lanjutan terkait pengaruh kepemimpinan ketua kelompok terhadap tingkat kemandirian anggota kelompok tani, seperti faktor internal dan eksternal yang mempengaruhi tingkat

\footnotetext{
Terpadu Padi Sawah. Skripsi. Fakultas Pertanian. Universitas Sebelas Maret. $S$

$123456789 / 64972 / 6 / \mathrm{BAB} \% 20 \mathrm{IV}$ $\% 20$ Metode $\% 20$ Penelitian.pdf. diunduh pada tanggal 04-02-17 jam 04.52
}

Notoatmodjo, Soekidjo. 2007. Pendidikan dan Perilaku Kesehatan. Rineka Cipta. Jakarta.

Onong, U. E. 1981. Kepemimpinan dan Komunikasi. Penerbit Alumni. Bandung. Republik Indonesia. 2003. Undang-Undang No. 13 Tahun 2003 tentang Ketenagakerjaan. Lembaran Negara RI Tahun 2013. Sekretariat Negara, Jakarta.

Sugiyono. 2007. Statistika untuk Penelitian. Bandung: Alfabeta.

Pengaruh Kepemimpinan Ketua Kelompok Terhadap

TRI RAHAYU dan ROSDA AMALIA

Tingkat Kemandirian Anggota Kelompok Di Gabungan

Petani Organik (Gpo) Nyi-Sri Kecamatan Cianjur

Kabupaten Cianjur 
\begin{tabular}{l} 
Pendidikan Pendekatan \\
\hline Kualitatif, dan ReDtatif, \\
Alfabeta
\end{tabular}

2012. Metodologi Penelitian

Kuantitatif Kualitatif dan $\mathrm{R} \& D$.

Bandung : Alfabeta

Soetomo. 2012. Pembangunan

Masyarakat

Merangkai

Zakariyya. 2010. Hubungan Kepemimpinan

Ketua Kelompok Tani Dengan
Sebuah Kerangka'.

Yogyakarta : Pustaka Pelajar.

Unang Yunasaf. 2005. Kepemimpinan Ketua Kelompok dan Hubungannya dengan Keefektifan

Kelompok.http://pustaka.unpad. ac.id/wp-

content/uploads/2009/11/kepem impinan ketua kelompok.pdf. diunduh pada tanggal 29-01-2017 jam

Efektivitas Kelompok Tani Di Kecamatan Pacitan Kabupaten Pacitan. Skripsi. Fakultas Pertanian. Universitas Sebelas Maret. 